\title{
Kajian Distribusi Sedimentasi Terhadap Umur Rencana Waduk Ciawi Di KabupatenBogor
}

\author{
Wulandari Pingkan Siwu ${ }^{1}$, Sri Sangkawati ${ }^{2}$, Ignatius Sriyana ${ }^{3}$ \\ Magister Teknik Sipil, Departemen Teknik Sipil Fakultas, Teknik Sipil Universitas Diponegoro ${ }^{\mathbf{1} 2.3}$ \\ Email:wulanpingkan@student.undip.ac.id ${ }^{1}$, srisangkawati@gmail.com², \\ sriyana@lecturer.undip.ac.id ${ }^{3}$ \\ DOI: http://dx.doi.org/10.31869/rtj.v4i2.2321
}

\begin{abstract}
Abstrak: Waduk Ciawi terletak di bagian hulu sungai Ciliwung di Desa Cipayung Kecamatan Megamendung Kabupaten Bogor Provinsi Jawa Barat. Waduk Ciawi merupakan waduk eka guna (single purpose) yang dibangun untuk pengendalian debit puncak banjir maksimum di hulu Sungai Ciliwung dengan konsep dry dam. Perencanaan suatu bendungan tentunya tidak akan pernah terlepas dari rencana usia waduk, dalam perencanaannya selalu memperhitungkan jumlah sedimen yang akan masuk ke dalam waduk selama usia guna waduk karena pengendapan sedimen di dead storing dapat berdampak pada usia guna waduk, sehingga perlu dilakukan analisis untuk memprediksi besarnya sedimentasi dan pola distribusi sedimen pada Waduk Ciawi dalam upaya optimalisasi pengelolaan waduk. Memprediksi besarnya sedimentasi di Waduk Ciawi dilakukan berdasarkan pengaruh sedimen layang dan analisis distribusi sedimen menggunakan Metode Empiris Pengurangan Luas (Empirical Area Reduction Method). Berdasarkan hasil analisis, jumlah sedimen yang mengendap di Waduk Ciawi sepanjang umur rencana adalah sebesar $206.687,60 \mathrm{~m}^{3}$, dengan elevasi nol baru (new zero elevation) waduk setelah tahun ke 50 yaitu pada +512 m dan kapasitas tampungan efektif yang terisa sampai dengan umur efektif tercapai $\left(\mathrm{T}_{50}\right)$ sebesar $6.178 .131 \mathrm{~m}^{3}$. Secara teoritis Waduk Ciawi masih bisa berfungsi dengan baik sampai dengan umur rencana terlampaui.
\end{abstract}

Kata Kunci: Waduk Ciawi, Usia Guna waduk, Laju Sedimentasi, Distribusi Sedimentasi.

\section{PENDAHULUAN}

Pembangunan waduk dilakukan untuk pengelolaan sumber daya air yang berfungsi untuk penyediaan air baku, penyediaan air irigasi, pengendalian banjir dan/atau pembangkit listrik tenaga air (Kementerian Pekerjaan Umum dan Perumahan Rakyat, 2015). Berdasarkan fungsinya, waduk diklasifikasikan menjadi dua jenis yaitu waduk eka guna (single purpose) yaitu waduk yang dioperasikan untuk memenuhi satu kebutuhan saja, misalnya untuk kebutuhan khusus air irigasi, khusus air baku, khusus PLTA ataupun khusus pengendali banjir, dan waduk multi guna (multi purpose) yaitu yang berfungsi untuk memenuhi berbagai kebutuhan misalnya untuk memenuhi kebutuhan air, irigasi, air baku, pengendali banjir dan PLTA (Ernawan \& Putri, 2017).

Waduk Ciawi merupakan waduk eka guna (single purpose) yang dibangun untuk pengendalian debit puncak banjir maksimum di hulu Sungai Ciliwung dengan konsep dry dam, dimana pada saat awal musim hujan, elevasi muka air waduk diatur berada pada elevasi yang rendah sehingga pada awal banjir, debit banjir akan mengalir secara bebas melalui terowongan (Balai Besar Wilayah
Sungai Ciliwung Cisadane, 2016). Bendungan kering (dry dam) adalah daerah tangkapan air yang dirancang untuk menampung air yang berlebih pada saat banjir terjadi untuk jangka waktu singkat yaitu $24-48$ jam, hal ini untuk mencegah banjir terjadi di bagian hilir (https://albertawater.com/flood-mitigation/drydams). Waduk Ciawi merupakan waduk pertama di Indonesia yang menerapkan konsep dry dam (Balai Besar Wilayah Sungai Ciliwung Cisadane, 2016).

Perencanaan suatu bendungan tentunya tidak pernah terlepas dari rencana usia guna waduk, sehingga dalam perencanaan suatu waduk selalu memperhitungkan jumlah sedimen yang akan masuk ke dalam waduk selama usia guna waduk (Achsan, Bisri, \& Suharyanto, 2015). Usia guna waduk ditentukan berdasarkan lamanya volume tampungan mati (dead storage) terisi oleh sedimen (Mukti, 2019). Sedimentasi di waduk biasanya berasal dari erosi lahan dan sungai sepanjang pengalirannya yang tersangkut sampai ke waduk dan akhirnya mengendap di dalam waduk (Wulandari, 2007). Setiap waduk memiliki pola distribusi sedimen yang berbeda-beda karena masing-masing mempunyai karakteristik dan sistem yang 
berbeda. Selain itu, bentuk waduk, sistem operasi waduk dan ukuran butiran sedimen juga mempengaruhi distribusi sedimen di waduk. Pola distribusi sedimen pada waduk berguna dalam memperkirakan volume efektif yang tersedia sepanjang umur efektif waduk. Pengendapan sedimen di dead storage dapat berdampak pada usia guna waduk (Setyono, 2011).

Volume suatu tampungan secara bertahap tentunya akan mengalami pengurangan karena akumulasi sedimen yang masuk ke dalam waduk akan mengakibatkan terjadinya perubahan pada luas dan volume tampungan waduk (Issa, Al-Ansari, Sherwany, \& Knutsson, 2015). Selain itu berkurangnya volume tampungan efektif pada waduk akibat sedimentasi tentunya akan berpengaruh terhadap kapasitas manfaat waduk (Soewarno \& Syariman, 2008).

Berdasarkan permasalahan tersebut maka dibutukan kajian untuk memprediksi seberapa besar sediementasi yang mengendap di dalam Waduk Ciawi, dan memprediksi akumulasi sedimen pada tiap-tiap elevasi di Waduk Ciawi. Memprediksi besarnya sedimentasi di Waduk Ciawi dilakukan berdasarkan pengaruh sedimen layang dan analisis distribusi sedimen untuk mengetahui akumulasi sedimen pada tiap-tiap elevasi waduk menggunakan The Empirical Area Reduction Method (Metode Empiris Pengurangan Luas).

\section{METODE PENELITIAN}

Analisis yang pertama adalah memprediksi besarnya sedimen yang mengendap di waduk. Memprediksi besarnya sedimentasi yang terjadi di Waduk Ciawi berdasarkan pengaruh sedimen layang. Pengukuran sedimen layang (suspended load) dihitung dengan menggunakan persamaan (Asdak, 1995):

$Q_{s}=0,0864 \cdot Q_{w} \cdot C Q_{s}=0,0864 \cdot Q_{w} \cdot C$

dengan:

Qs = Debit sedimen (ton/hari)

$\mathrm{C}=$ konsentrasi sedimen (mg/liter)

Qw = debit aliran $\left(\mathrm{m}^{3} /\right.$ detik)

0,0864 merupakan faktor perubahan unit

Dari perhitungan tersebut dibuat lengkung laju sedimen yang merupakan garis regresi antara debit air (Qw) dan debit sedimen (Qs) dengan persamaan.

$Q_{s}=a \cdot Q_{w}{ }^{b} Q_{s}=a \cdot Q_{w}{ }^{b}$

dengan:

Qs = debit sedimen harian (ton/hari)

a $\quad$ koefisien

$\mathrm{b}=$ eksponen

Memprediksi besarnya sedimen yang mengendap di waduk yaitu dengan mencari nilai efisiensi tangkapan sedimen (trap efficiency). Efisiensi tangkapan sedimen pada suatu waduk tergantung pada kapasitas tampungan waduk dengan jumlah air yang masuk ke dalam waduk dalam satu tahun (Legowo, Hadihardaja, \& Rabuanawati, 2010). Nilai trap efficiency dinyatakan pada grafik hubungan antara kapasitas tampungan waduk dengan inflow tahunan seperti pada Gambar 1 . Niai trap efficiency akan berkurang seiring dengan beroperasinya waduk karena kapasitas tampungan waduk akan mengalami pengurangan yang diakibatkan oleh sedimen.

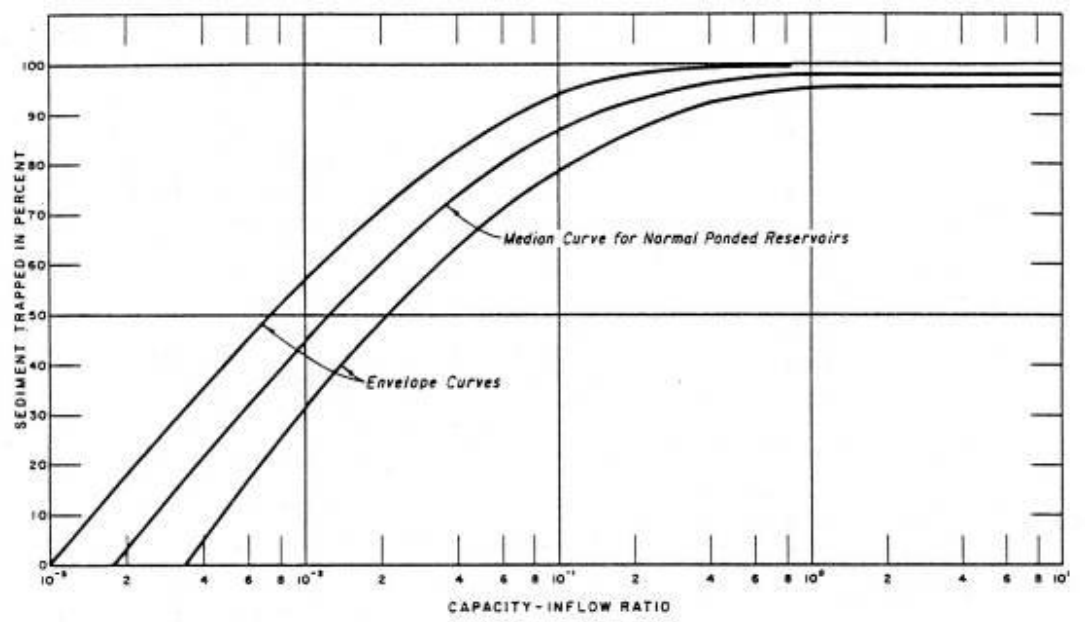

Gambar 1 Grafik hubungan Capasity - inflow ratio

Sumber : (Brune, 1953) 
Selanjutnya memprediksi distribusi sedimen di waduk. Pola distribusi waduk dipengaruhi oleh beberapa factor. Factor yang paling mempengaruhi adalah jenis muatan sedimen, ukuran dan bentuk waduk serta lokasi dan ukuran outlet (Priyantoro, 1987). Ada beberapa metode yang digunakan untuk menentukan sebaran sedimentasi di waduk diantaranya metode penambahan luas dan pengurangan luas (area increment and empirical area reduction method) (Hosseinjanzadeh, Hosseini, Kaveh, \& Mousavi, 2015). Analisis distribusi sedimen dalam penelitian ini menggunakan Metode Empiris Pengurangan Luas (Empirical Area Reduction Method), karena metode ini memiliki tingkat kesalahan yang relatif lebih kecil dibandingkan dengan metode empiris penambahan luas (Tukaram, Nimbalkar, \& Gidde, 2016).

Metode ini menerapkan bahwa distribusi sedimen di waduk tergantung pada beberapa faktor yaitu cara pengoperasian waduk, tekstur dan ukuran partikel sedimen, bentuk waduk dan volume sedimen yang mengendap di waduk (Yang, 2003). Langkah-langkah perhitungan distribusi di waduk adalah sebagai berikut (Morris \& Fan, 2009).

1) Menentukan besarnya jumlah sedimen yang mengendap di waduk.

2) Memilih salah satu tipe kurva berdasarkan :

a) Bentuk waduknya dapat ditentukan berdasarkan tipe kurva seperti pada Tabel 1, dan untuk kemiringan $m$ didapat dari hubungan antara kedalaman dengan kapasitas waduk yang diplotkan pada kertas logaritma pada Gambar 2. Apabila nilai $\mathrm{m}$ bervariasi maka dapat diambil nilai $\mathrm{m}$ yang paling dominan.

Tabel 1 Hubungan bentuk waduk dan tipe kurva

\begin{tabular}{c|c|c}
\hline Bentuk Waduk & $\begin{array}{c}\text { Tipe } \\
\text { kurva }\end{array}$ & m \\
\hline Danau & I & $3,5-4,5$ \\
\hline Dataran - kaki bukit & II & $2,5-3,5$ \\
\hline Bukit - pegunungan & III & $1,5-2,5$ \\
\hline Pegunungan & IV & $1,0-1,5$ \\
\hline
\end{tabular}

Sumber: (Morris \& Fan, 2009)

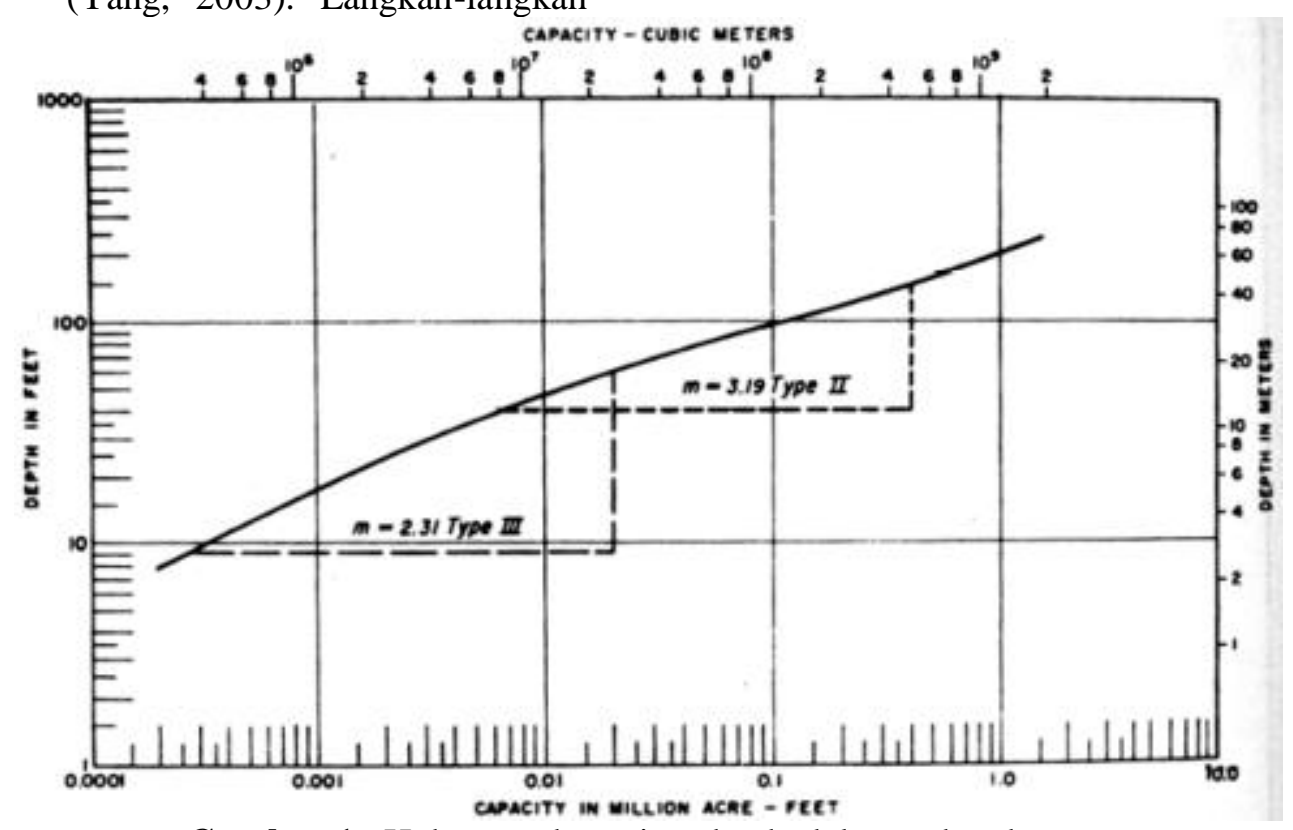

Gambar 1 Hubungan kapasitas dan kedalaman bendungan

Sumber: (Morris \& Fan, 2009)

b) Sistem operasi waduk, dapat ditentukan berdasarkan Tabel 2.

Tabel 2 Hubungan sistem operasi waduk dan tipe kurva

\begin{tabular}{c|c|c|c|c}
\hline $\begin{array}{c}\text { Operasi } \\
\text { waduk }\end{array}$ & $\begin{array}{c}\text { Tingkat } \\
\text { operasion } \\
\text { al }\end{array}$ & Klasifikasi & $\begin{array}{c}\text { Tip } \\
\text { e }\end{array}$ & $\begin{array}{c}\text { Tipe } \\
\text { kurv } \\
\mathbf{a}\end{array}$ \\
\hline Sedime & I & Danau & I & I \\
\hline
\end{tabular}

\begin{tabular}{c|c|c|c|c}
\hline $\mathrm{n}$ & & Dataran- & II & I atau \\
kaki bukit & II & II \\
Bukit - & & II \\
m di & & $\begin{array}{c}\text { Pegununga } \\
\text { waduk }\end{array}$ & & \\
& & n & & \\
\hline $\begin{array}{c}\text { Surutan } \\
\text { muka } \\
\text { air }\end{array}$ & II & Danau & I & I atau \\
Dataran- & II & II \\
kaki bukit & II & II \\
\hline
\end{tabular}


Vol. 4 No.2 Juni 2021

http://jurnal.umsb.ac.id/index.php/RANGTEKNIKJOURNAL

\begin{tabular}{|c|c|c|c|c|}
\hline $\begin{array}{l}\text { waduk } \\
\text { sedang }\end{array}$ & & $\begin{array}{c}\text { Bukit - } \\
\text { Pegununga } \\
n\end{array}$ & & $\begin{array}{c}\text { II } \\
\text { atau } \\
\text { III }\end{array}$ \\
\hline $\begin{array}{c}\text { Surutan } \\
\text { muka } \\
\text { air } \\
\text { waduk } \\
\text { cukup } \\
\text { besar }\end{array}$ & III & $\begin{array}{c}\text { Danau } \\
\text { Dataran- } \\
\text { kaki bukit } \\
\text { Bukit - } \\
\text { Pegununga } \\
\text { n }\end{array}$ & $\begin{array}{l}\text { I } \\
\text { II } \\
\text { III }\end{array}$ & $\begin{array}{c}\text { II } \\
\text { II } \\
\text { atau } \\
\text { III } \\
\text { III }\end{array}$ \\
\hline $\begin{array}{c}\text { Dalam } \\
\text { keadaan } \\
\text { normal } \\
\text { waduk } \\
\text { kosong } \\
\end{array}$ & IV & Semua & & IV \\
\hline
\end{tabular}

Sumber: (Morris \& Fan, 2009)

c) Ukuran butiran sedimen, dapat ditentukan berdasarkan Tabel 3

Tabel 3 Hubungan ukuran butiran sedimen waduk dan tipe kurva

\begin{tabular}{c|c}
\hline $\begin{array}{c}\text { Ukuran butiran sedimen yang } \\
\text { dominan }\end{array}$ & Tipe \\
\hline Pasir atau material kasar & I \\
\hline Lanau & II \\
\hline Lempung & II \\
\hline
\end{tabular}

Sumber: (Morris \& Fan, 2009)
3) Menentukan fungsi tak berdimensi (F) tiaptiap elevasi untuk menperoleh kedalam nol baru pada waduk yaitu dengan persamaan $F=\frac{s-V_{h}}{H A_{h}} F=\frac{s-V_{h}}{H A_{h}}$ dengan:

$\mathrm{S}=$ total sedimen yang mengendap $\left(\mathrm{m}^{3}\right)$

$\mathrm{H}=$ kedalaman waduk mula-mula $(\mathrm{m})$

$\mathrm{Vh}=$ volume total waduk pada kedalaman elevasi $\mathrm{H}\left(\mathrm{m}^{2}\right)$

Menentukan kedalaman relatif (p) dihitung dengan persamaan:

$p=\frac{h}{H} p=\frac{h}{H}$

dengan:

$\mathrm{h}=$ kedalaman pada elevasi $\mathrm{H}(\mathrm{m})$

$\mathrm{H} \quad=$ kedalaman total mula-mula $(\mathrm{m})$

Menentukan elevasi dari endapan sedimen yang mencapai bendungan yang merupakan titik dasar kedalaman baru (new zero elevation) berdasarkan hasil perpotongan antara garis yang terbentuk melalui hubungan titik-titik nilai $\mathrm{F}$ dan nilai kedalam relatif $(p)$ dengan menggunakan grafik seperti pada Gambar 2.

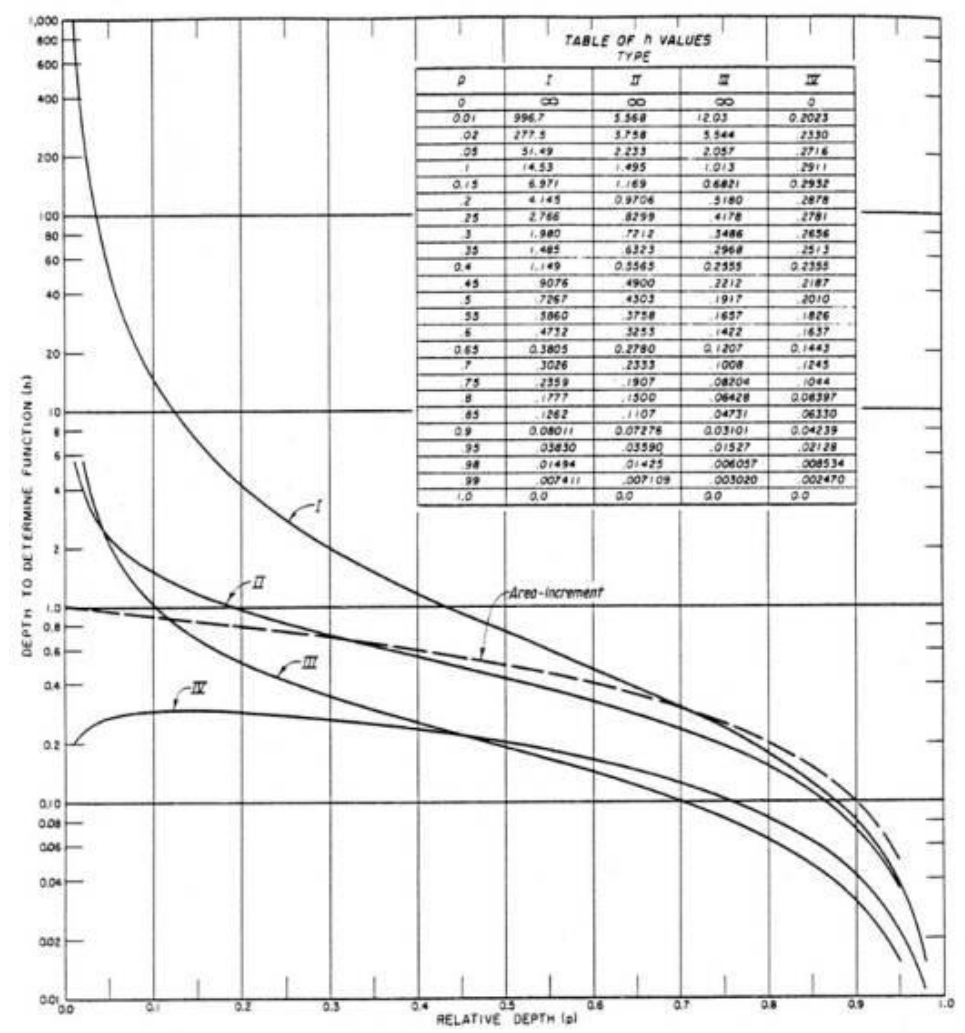

Gambar 2 Grafik hubungan kedalam relatif dan nilai $\mathrm{F}$ 
4) Menentukan luas sedimen relatif (Ap) pada setiap kedalaman waduk berdasarkan tipe waduk yang sesuai dengan menggunakan persamaan berikut:

Tipe I: $A p=5,047 p^{1,85}(1-p)^{0,36}$ $A p=5,047 p^{1,85}(1-p)^{0,36}$

Tipe II: $\quad A p=2,487 p^{0,57}(1-p)^{0,41 f}$ $A p=2,487 p^{0,57}(1-p)^{0,41 f}$

Tipe III: $\quad A p=16,967 p^{1,15}(1-p)^{2,32}$ $A p=16,967 p^{1,15}(1-p)^{2,32}$

Tipe IV: $A p=1,48 p^{-0,25}(1-p)^{1,34}$ $A p=1,48 p^{-0,25}(1-p)^{1,34}$

dengan:

$\mathrm{Ap}=\quad$ luas sedimen relatif

$\mathrm{p}=$ kedalaman waduk relatif diukur dari dasar

5) Menghitung luas terkoreksi (Ao) di mana besarannya sama dengan luas tampungan awal pada elevasi nol baru dibagi dengan luas relatifnya.

6) Menghitung luas terdistribusi pada tiap elevasi dengan cara luas tampungan awal dikalikan dengan luas terkoreksi pada poin (5) untuk elevasi di atas nol baru.

7) Menghitung volume sedimen yang mengendap pada setiap elevasi dengan persamaan berikut:

$V_{s h}=\frac{a_{h}+a_{h-1}}{2} \cdot \Delta h V_{s h}=\frac{a_{h}+a_{h-1}}{2} \cdot \Delta h$

dengan:

Vsh $=\quad$ volume $\quad$ sedimen pada

kedalaman $\mathrm{h}\left(\mathrm{m}^{3}\right)$

$\mathrm{Ah}=$ luas terdistribusi pada kedalaman $\mathrm{h}\left(\mathrm{m}^{2}\right)$

ah-1 = luas terdistribusi pada kedalaman h-1 $\left(\mathrm{m}^{2}\right)$

$\Delta \mathrm{h}=\quad$ selisih kedalaman $(\mathrm{m})$

8) Menghitung volume efektif waduk setelah T-tahun di mana besarnya sama dengan tampungan awal waduk dikurangi volume sedimen yang mengendap pada setiap elevasi pada poin (7).

\section{HASIL DAN PEMBAHASAN}

Sedimen yang Mengendap di Waduk

Memprediksi besarnya sedimen yang mengendap di Waduk Ciawi dihitung berdasarkan pengukuran sedimen layang, dan untuk sampel sedimen layang diambil dari stasiun pengukuran Ciboto tahun 2015 seperti disajikan pada Tabel 4. Dari hasil perhitungan sedimen layang dibuat lengkung laju sedimen (sediment rating curve) seperti pada Gambar 3 dan diperoleh persamaan regresi $\mathrm{y}=$ $0,4604 \mathrm{x}^{2,1219}$ dengan koefisien korelasi (R) sebesar 0,826 .

Tabel 4 Hasil perhitungan sedimen layang pada Stasiun Cibogo tahun 2015

\begin{tabular}{c|c|c|c|c}
\hline No & Tanggal & $\begin{array}{c}\mathbf{Q w} \\
\left(\mathbf{m}^{3} / \mathbf{d t}\right)\end{array}$ & $\begin{array}{c}\text { Kadar } \\
\mathbf{s e d i m e n} \\
(\mathbf{m g} / \mathbf{l})\end{array}$ & $\begin{array}{c}\mathbf{Q s} \\
(\mathbf{t o n} / \mathbf{h r})\end{array}$ \\
\hline 1 & $\begin{array}{c}02 \text { Oktober } \\
2015\end{array}$ & 2,4 & 13,1 & 2,72 \\
\hline 2 & $\begin{array}{c}05 \text { Oktober } \\
2015\end{array}$ & 2,5 & 19,7 & 4,26 \\
\hline 3 & $\begin{array}{c}07 \text { Oktober } \\
2015\end{array}$ & 2,7 & 13,1 & 3,07 \\
\hline 4 & $\begin{array}{c}09 \text { Oktober } \\
2015\end{array}$ & 3,0 & 19,7 & 5,11 \\
\hline 5 & $\begin{array}{c}12 \text { Oktober } \\
2015\end{array}$ & 2,8 & 9,2 & 2,23 \\
\hline 6 & $\begin{array}{c}15 \text { Oktober } \\
2015\end{array}$ & 2,4 & 19,7 & 4,09 \\
\hline 7 & $\begin{array}{c}19 \text { Oktober } \\
2015\end{array}$ & 2,4 & 8,2 & 1,70 \\
\hline 8 & $\begin{array}{c}25 \text { Oktober } \\
2015\end{array}$ & 6,0 & 56,5 & 29,29 \\
\hline 9 & $\begin{array}{c}26 \text { Oktober } \\
2015\end{array}$ & 6,5 & 34,5 & 19,36 \\
\hline 10 & $\begin{array}{c}29 \text { Oktober } \\
2015\end{array}$ & 2,4 & 19,7 & 4,09 \\
\hline 11 & $\begin{array}{c}30 \text { Oktober } \\
2015\end{array}$ & 2,4 & 19,7 & 4,09 \\
\hline
\end{tabular}

Sumber: (Balai Besar Wilayah Sungai Ciliwung Cisadane, 2016) 
Vol. 4 No.2 Juni 2021

http://jurnal.umsb.ac.id/index.php/RANGTEKNIKJOURNAL

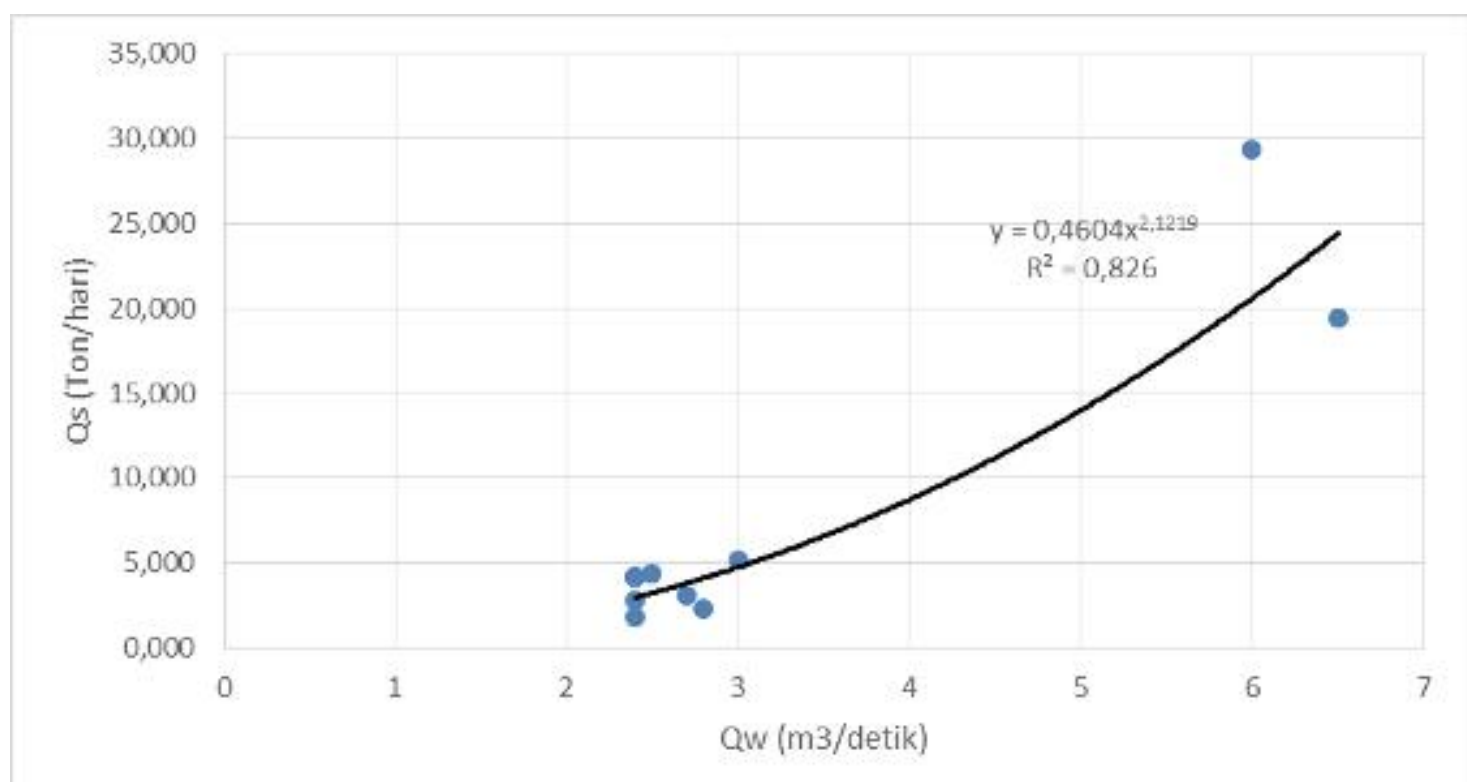

Gambar 3 Sediment Rating Curve (Lengkung Laju Sedimen)

Berdasarkan dari persamaan regresi tersebut debit sedimentasi yang ada di Waduk Ciawi dapat ditentukan. Hasil perhitungan debit sedimentasi disajikan pada Tabel 5.

Tabel 5Debit sedimen tahun 2015

\begin{tabular}{c|c}
\hline Bulan & Qs (ton/bln) \\
\hline Januari & 732,24 \\
\hline Februari & 834,21 \\
\hline Maret & 654,43 \\
\hline April & 688,93 \\
\hline Mei & 624,93 \\
\hline Juni & 215,74 \\
\hline Juli & 152,74
\end{tabular}

\begin{tabular}{c|c}
\hline Agustus & 171,95 \\
\hline September & 145,59 \\
\hline Oktober & 143,90 \\
\hline November & 593,31 \\
\hline Desember & 655,78 \\
\hline Total & 5613,74 \\
\hline
\end{tabular}

Kapasitas tampungan Waduk Ciawi adalah sebesar 14,7 juta $\mathrm{m}^{3}$ dengan inflow sebesar 155.840.400 $\mathrm{m}^{3}$ (Balai Besar Wilayah Sungai Ciliwung Cisadane, 2016), maka nilai trap efficiency adalah sebesar $71 \%$ seperti pada Gambar 4.

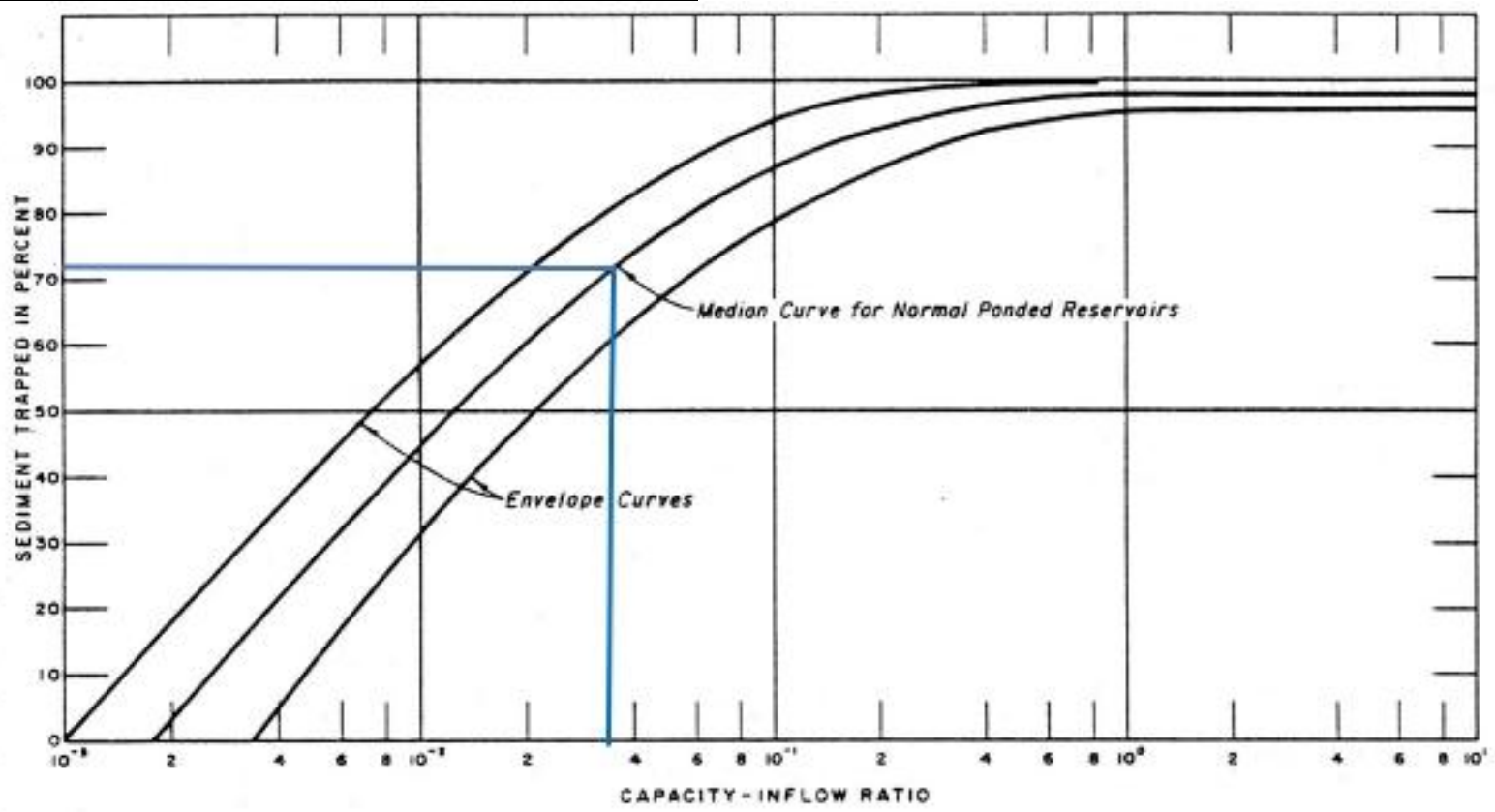

Gambar 4 Grafik hubungan Capasity - inflow ratio 
Berdasarkan hasil perhitungan jumlah sedimen layang pada Tabel 5 , diperoleh total sedimen potensial yang masuk ke waduk adalah sebesar 5.613,74 ton/tahun, sehingga total sedimen yang mengendap di Waduk Ciawi dapat dihitung yaitu sebesar 4.547,60 ton/tahun.

Waduk Ciawi direncanakan memiliki umur layanan selama 50 tahun, sehingga total volume sedimen yang mengendap di waduk dapat dihitung yaitu sebesar 206.687,60 $\mathrm{m}^{3}$.

\section{Distribusi Sedimen di Waduk}

Prediksi distribusi sedimen di Waduk Ciawi dihitung dengan Metode Empiris Pengurangan Luas dan dari hasil perhitungan diperoleh elevasi nol baru (new zero elevation) pengendapan sedimen yaitu pada $+512,00$ meter. Akumulasi sedimen pada tiap-tiap elevasi waduk disajikan pada Tabel 6 .

Tabel 6Hasil perhitungan luas dan volume tampungan sampai usia guna waduk berakhir

\begin{tabular}{|c|c|c|c|c|c|c|}
\hline \multirow{2}{*}{ No } & \multirow{2}{*}{ Elevasi } & \multirow{2}{*}{$\underset{n}{\text { Kedalama }}$} & \multicolumn{2}{|c|}{ Awal Operasi $\left(\mathbf{T}_{0}\right)$} & \multicolumn{2}{|c|}{ Setelah 50 Tahun $\left(\mathbf{T}_{50}\right)$} \\
\hline & & & Luas $^{2}$ & Vol. $\mathrm{m}^{3}$ & ${\text { Luas } \mathrm{m}^{2}}^{2}$ & Vol. $\mathrm{m}^{3}$ \\
\hline 1 & 551 & 46 & $406.051,46$ & $6.383 .234,41$ & 406.051 & 6.178 .131 \\
\hline 2 & 550 & 45 & $391.174,71$ & $5.984 .644,46$ & 391.117 & 5.779 .570 \\
\hline 3 & 549 & 44 & $375.226,69$ & $5.601 .471,42$ & 375.079 & 5.396 .499 \\
\hline 4 & 548 & 43 & $359.655,56$ & $5.234 .057,79$ & 359.401 & 5.029 .287 \\
\hline 5 & 547 & 42 & $346.661,36$ & $4.880 .919,25$ & 346.284 & 4.676 .464 \\
\hline 6 & 546 & 41 & $331.851,23$ & $4.541 .689,90$ & 331.340 & 4.337 .679 \\
\hline 7 & 545 & 40 & $319.050,91$ & $4.216 .259,81$ & 318.394 & 4.012 .833 \\
\hline 8 & 544 & 39 & $306.062,56$ & $3.903 .725,57$ & 305.250 & 3.701 .034 \\
\hline 9 & 543 & 38 & $291.806,77$ & $3.604 .819,23$ & 290.828 & 3.403 .024 \\
\hline 10 & 542 & 37 & $272.109,99$ & $3.322 .918,20$ & 270.956 & 3.122 .189 \\
\hline 11 & 541 & 36 & $259.026,56$ & $3.057 .376,82$ & 257.689 & 2.857 .893 \\
\hline 12 & 540 & 35 & $243.073,89$ & 2.806 .358 .88 & 241.543 & 2.608 .319 \\
\hline 13 & 539 & 34 & $230.278,96$ & $2.569 .721,28$ & 228.546 & 2.373 .303 \\
\hline 14 & 538 & 33 & $217.149,41$ & $2.346 .039,21$ & 215.206 & 2.151 .459 \\
\hline 15 & 537 & 32 & $204.181,70$ & $2.135 .406,92$ & 202.019 & 1.942 .879 \\
\hline 16 & 536 & 31 & $192.198,70$ & $1.937 .246,91$ & 189.808 & 1.746 .996 \\
\hline 17 & 535 & 30 & $178.851,04$ & $1.751 .762,07$ & 176.223 & 1.564 .021 \\
\hline 18 & 534 & 29 & $166.144,04$ & $1.579 .303,55$ & 163.269 & 1.394 .314 \\
\hline 19 & 533 & 28 & $152.645,08$ & $1.419 .956,65$ & 149.514 & 1.237 .970 \\
\hline 20 & 532 & 27 & $138.812,02$ & $1.274 .282,84$ & 135.415 & 1.095 .561 \\
\hline 21 & 531 & 26 & $127.575,55$ & $1.141 .128,57$ & 123.902 & 965.942 \\
\hline 22 & 530 & 25 & $117.819,68$ & $1.018 .463,29$ & 113.859 & 847.093 \\
\hline 23 & 529 & 24 & $108.791,23$ & $905.187,82$ & 104.533 & 737.927 \\
\hline 24 & 628 & 23 & $101.463,13$ & $800.081,93$ & 96.895 & 637.234 \\
\hline 25 & 527 & 22 & $95.375,00$ & $701.678,56$ & 90.485 & 543.560 \\
\hline 26 & 526 & 21 & $86.893,16$ & $610.577,39$ & 81.688 & 457.516 \\
\hline 27 & 525 & 20 & $79.268,50$ & $527.525,73$ & 73.694 & 379.865 \\
\hline 28 & 524 & 19 & $65.239,94$ & $455.385,27$ & 59.300 & 313.482 \\
\hline 29 & 523 & 18 & $58.159,03$ & $393.719,67$ & 51.838 & 257.947 \\
\hline 30 & 522 & 17 & $52.881,32$ & $338.220,41$ & 46.160 & 208.969 \\
\hline 31 & 521 & 16 & $47.322,08$ & $288.144,43$ & 40.181 & 165.824 \\
\hline 32 & 520 & 15 & $41.811,54$ & $243.606,04$ & 34.229 & 128.647 \\
\hline 33 & 519 & 14 & $38.211,28$ & $203.608,14$ & 30.161 & 96.466 \\
\hline 34 & 518 & 13 & $34.864,59$ & $167.082,98$ & 26.319 & 68.239 \\
\hline 35 & 517 & 12 & $28.645,95$ & $135.378,57$ & 19.571 & 45.344 \\
\hline 36 & 516 & 11 & $24.001,12$ & $109.089,25$ & 14.360 & 28.413 \\
\hline 37 & 515 & 10 & $20.736,98$ & $86.740,08$ & 10.483 & 16.011 \\
\hline 38 & 514 & 9 & $17.981,69$ & $67.397,10$ & 7.061 & 7.256 \\
\hline 39 & 513 & 8 & $15.424,40$ & $50.710,40$ & 3.768 & 1.858 \\
\hline
\end{tabular}


Vol. 4 No.2 Juni 2021

http://jurnal.umsb.ac.id/index.php/RANGTEKNIKJOURNAL

\begin{tabular}{l|l|l|l|l|l|l}
\hline 40 & 512 & 7 & $12.479,21$ & $36.784,57$ & 0 & 0 \\
\hline 41 & 511 & 6 & $25.454,45$ & $10.218,64$ & 0 & 0 \\
\hline
\end{tabular}

Berdasarkan dari hasil perhitungan sedimen pada tiap-tiap elevasi diperoleh kurva lengkung kapasitas tampungan waduk yaitu pada tahun awal operasi waduk $\left(\mathrm{T}_{0}\right)$ dan tahun umur efektif berakhir $\left(\mathrm{T}_{50}\right)$. Kurva lengkung kapasitas disajikan pada Gambar 5.

Kapasitas tampungan Waduk Ciawi setelah umur efektif berakhir $\left(\mathrm{T}_{50}\right)$ pada elevasi muka air normal terjadi pengurangan kapasitas tampungan yaitu sebesar $4,50 \%$ menjadi $4.337 .579 \mathrm{~m}^{3}$ dari kapasitas awal operasi 4.542.689,90 $\mathrm{m}^{3}$, sedangkan pada elevasi muka air minimum kapasitas tampungan masih sebesar 10.218,64 $\mathrm{m}^{3}$ atau tidak terjadi pengurangan kapasitas dari awal operasi waduk dan pada elevasi muka air maksimum terjadi pengurangan kapasitas tampungan

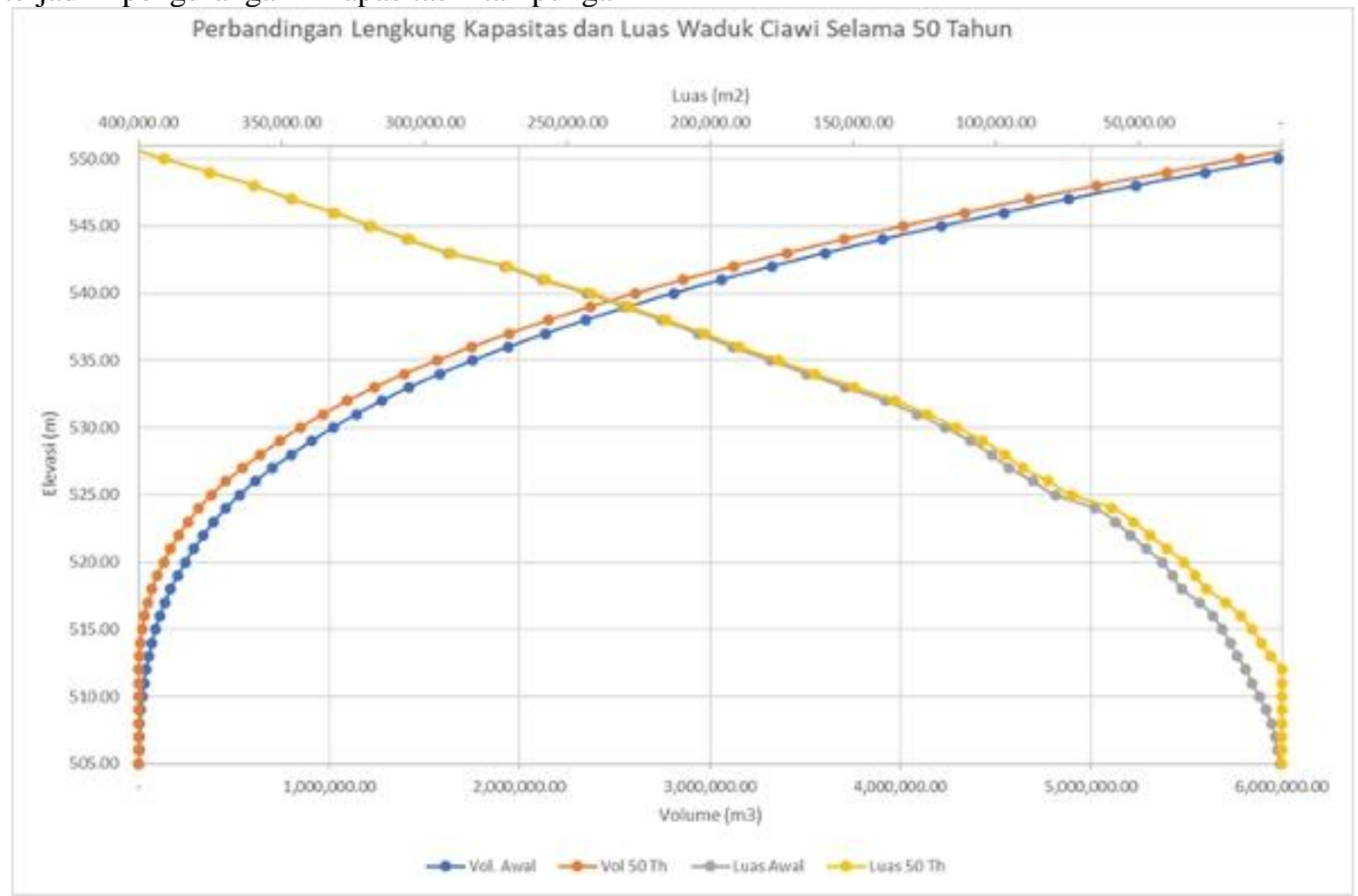

Gambar 5 Lengkung kapasitas - luas tampungan Waduk Ciawi

\section{PENUTUP}

Berdasarkan hasil pengukuran sedimen layang diperoleh total sedimen yang mengendap di Waduk Ciawi adalah sebesar 4.547,60 ton/tahun. Setelah umur efektif tercapai $\left(\mathrm{T}_{50}\right)$, volume sedimen yang mengendap di Waduk Ciawi diprediksi sebesar $206.688 \mathrm{~m}^{3}$, dimana kapasitas tampungan normal berkurang sebesar $4,50 \%$ dan tersisa sebesar $3,21 \%$ menjadi $6.178 .131 \mathrm{~m}^{3}$ dari kapasitas awal 6.383.234,41 $\mathrm{m}^{3}$.

Perubahan kapasitas pada tiap tampungan waduk pada tahun awal operasi waduk sampai dengan tahun umur efektif berakhir tidak terjadi perubahan yang signifikan, sehingga secara teoritis Waduk Ciawi masih dapat befungsi dengan baik sampai umur rencana terlampaui. Namun pengendapan sedimen pada elevasi muka air normal dan elevasi muka air minimum dapat menimbulkan permasalahan apabila tidak dilakukan monitoring maupun pemeliharaan terkait sedimentasi karena akan mempengaruhi fungsi waduk tersebut.
4.447.579 $\mathrm{m}^{3}$, sedangkan pada elevasi muka air minimum kapasitas tampungan masih sebesar 10.218,64 $\mathrm{m}^{3}$ atau tidak terjadi pengurangan kapasitas dan pada elevasi muka air maksimum terjadi pengurangan kapasitas tampungan sebesar 3,21\%.

Perubahan kapasitas pada tiap tampungan waduk pada tahun awal operasi waduk sampai dengan tahun umur efektif berakhir tidak 
terjadi perubahan yang signifikan, sehingga secara teoritis Waduk Ciawi masih dapat befungsi dengan baik sampai umur rencana terlampaui. Namun perlu dilakukan monitoring sedimentasi setiap tahun sekali untuk awal masa operasi waduk dan meyusun kegiatan pemeliharaan terkait sedimentasi waduk agar waduk dapat bermanfaat sampai dengan umur efektif.

\section{UCAPAN TERIMA KASIH}

Penulis mengucapkan terima kasih kepada Prof. Dr. Ir. Sri Sangkawati, MS dan Prof. Dr. Ir. Ignatius Sriyana, MS yang telah membimbing, memberi arahan dan masukan dalam penulisan ini.

\section{DAFTAR PUSTAKA}

Achsan, Bisri, M., \& Suharyanto, E. (2015). Analisis kecenderungan sedimentasi waduk bili- bili dalam upaya keberlanjutan usia guna waduk. Jurnal Pengairan, 6(1), 30-36.

Asdak, C. (1995). Hidrologi dan Pengelolaan Daerah Aliran Sungai. Yogyakarta: Gaja Mada University Press.

Balai Besar Wilayah Sungai Ciliwung Cisadane. (2016). Laporan Akhir Sertifikasi Desain Bendungan Ciawi dan Bendungan Sukamahi (Lanjutan). Jakarta.

Brune, G. M. (1953). Trap Efficiency of Reservoirs. Eos, Transactions American Geophysical Union, 34(3), 407-418.

Dry Dam. (n.d.). Retrieved February 18, 2020, from https://albertawater.com/floodmitigation/dry-dams

Ernawan, \& Putri, A. I. (2017). KAJIAN DISTRIBUSI SEDIMENTASI WADUK BENING KABUPATEN MADIUN (EMPERICAL AREA REDUCTION METHOD DAN AREA INCREMENT METHOD). Media Teknik Sipil, 15(1), 34-41.

Hosseinjanzadeh, H., Hosseini, K., Kaveh, K., \& Mousavi, S. F. (2015). New proposed method for prediction of reservoir sedimentation distribution. International Journal of Sediment Research, 30(3), 235-240.

Issa, E. I., Al-Ansari, N., Sherwany, G., \& Knutsson, S. (2015). Evaluation and modification of some empirical and semi-empirical approaches for prediction of area-storage capacity curves in reservoirs of dams. International Journal of Sediment Research, 32(1), 127-135.

Kementerian Pekerjaan Umum dan Perumahan Rakyat. (2015). PERATURAN MENTERI PEKERJAAN UMUM DAN PERUMAHAN RAKYAT REPUBLIK INDONESIA NOMOR 27/PRT/M/2015 TENTANG BENDUNGAN. https://doi.org/10.1377/hlthaff.2013.0625

Legowo, S., Hadihardaja, I. K., \& Rabuanawati, S. (2010). Pengoperasian dan Umur Guna Waduk (Studi Kasus : Waduk Cimeta Padalarang). Jurnal Teknik Sipil, 13(4), 183-200.

Morris, G. L., \& Fan, J. (2009). Reservoir Sedimentation Handbook, Design and Management of Dams, Reservoirs, and Watersheds for Sustainable Use. McGrawHill. Co. New York. USA.

Mukti, H. A. (2019). Erosion analysis in efforts to sustain the age of use of the kedungombo reservoir. International Journal of Scientific and Technology Research, 8(10), 1931-1940.

Priyantoro, D. (1987). Teknik Pengukuran Sedimen. Malang: Fakultas Teknik Universitas Brawijaya.

Setyono, E. (2011). Kajian Distribusi Sedimentasi Waduk Wonorejo, Tulungagung Jawa Timur. Media Teknik Sipil, 9(2), 132-141.

Soewarno, \& Syariman, P. (2008). Sedimentation Control: Part II. Intensive Measures the Inside of the Mrica Reservoir, Central Java. Journal of Applied Sciences in Environmental Sanitation, 3(1), 17-24.

Tukaram, S., Nimbalkar, P., \& Gidde, M. (2016). Comparison of area reduction method and area increment method for reservoir sedimentation distribution Case study Ujjani dam. International Journal of Research in Advanced Engineering and Technology, 2(3), 108111.

Wulandari, D. A. (2007). Penanganan sedimentasi waduk mrica. Berkala Ilmiah Teknik Keairan, 13(4), 264-271.

Yang, C. T. (2003). Sediment transport: theory and practice. Krieger Pub. 